\title{
Aerobic capacity of wistar rats: the effects of training and physical detraining at middle-aged
}

http://dx.doi.org/10.11606/1807-5509201800010085

\author{
Ana Carolina GHEZZI* \\ Lucieli Teresa CAMBRI**** \\ Gustavo Gomes de ARAUJO***** \\ José Diego BOTEZELLI* \\ Carla RIBEIRO* \\ Maria Alice Rostom de MELLO*
}

* Department of
Physical Education,
Institute of
Biosciences, São
Paulo State University,
Rio Claro, SP, Brazil.
**Department of
Physical Education,
Federal University of
Mato Grosso, Cuiabá,
MT, Brazil.
***Department of
Physical Education,
Federal University of
Alagoas, Maceió, AL,
Brazil.

* Department of Institute of

Biosciences, São

Paulo State University,

** Department of

Physical Education, Federal University of

Mato Grosso, Cuiabá,

MT, Brazil.

***Department of

Federal University of

Brazil.

\begin{abstract}
It has been shown that engaging in regular physical exercise yields short- and long-term health benefits, primarily by mitigating the risk for cardiovascular disease, but little information is known about physical deconditioning at aging process. The aim of the present study was to analyze the aerobic capacity, through maximal lactate steady state (MLSS), in Wistar rats of different ages (2, 4, 6 e 12 months ) and physical conditioning deconditioning responses in middle-aged rats. The results were significant for weight gain in the sedentary $(588 \pm 71 \mathrm{~g})$ and detraining animals $(576 \pm 62 \mathrm{~g})$ at 12 months, whereas the conditioned group maintained their original body weights - BW (515 $\pm 72 \mathrm{~g})$, similar at four ( $455 \pm 17 \mathrm{~g})$ and six months of age $(471 \pm 37 \mathrm{~g})$. MLSS decreased with age (2 months sedentary $(8.4 \pm 1 \%$ Body Weight, 4 months sedentary $(6.4 \pm 0.6 \%$ BW), 6 months sedentary $(5.8 \pm 1 \%$ BW), 12 months sedentary $(5.1 \pm 0.7 \% \mathrm{BW})$, but physical exercise was effective in attenuating the age-related loss of aerobic capacity after 12 months $(5.8 \pm 1.3 \%$ BW). The physical detraining $(5.3 \pm 0.4 \% \mathrm{BW})$ was similar at 12 months trained. The physical training in long term protected against the increased of the body weight and fat depots caused by aging, but, this effect was found by deconditioning physical. Additionally, the physical training attenuated the aerobic capacity loss due to aging process and this effect was maintained after detraining physical.
\end{abstract}

KeYwords: Aging; Metabolic Disease; Maximal Lactate Steady State; Physical Exercise; Sedentary; Rats Middle-aged.

\section{Introduction}

Aging is a natural process through which the body's physiologic functions and capacities diminish over time, especially from the third decade of life on when the progressive decline of functional capacity sets in. However, the speed at which this progressive loss of functional capacity occurs depends on various genetic factors, the presence of underlying health conditions and the lifestyle choices of the individual, including the practice of physical exercise ${ }^{1,2}$.

The adoption of a healthy lifestyle has been recommended for aging individuals as a way to both prolong and improve one's quality of life. Although, the activities and behaviors that constitute a healthy lifestyle may vary by context, it is reasonable to assume that most recommendations would involve 
some combination of a balanced diet and a physically active life ${ }^{3,4}$.

In this way, an appropriate level of cardiovascular fitness is protective against cardiovascular disease and inversely correlated with the presence of cardiovascular and metabolic risk factors ${ }^{5}$. Regular exercise and aerobic modalities, in particular, yield short and long-term health benefits by mitigating the risk factors for cardiovascular disease ${ }^{6}$, which is currently the primary cause of mortality for both males and females worldwide in developed and developing countries alike?

While physical activities are increasingly incorporated into the everyday lives of aging individuals, there is an attendant interest in better understanding the physiological effects that physical conditioning exerts on the aerobic capacity of active individuals.

The maximal lactate steady state (MLSS) is considered the "gold standard" for the assessment of aerobic capacity ${ }^{8}$. The MLSS is the highest blood lactate concentration during a exercise with constant workload without blood lactate accumulation?

Different studies used the MLSS for different goals, for assessment of cardiovascular or pulmonary health, evaluation of training programs, aerobic capacity, prescription of appropriate exercise intensity, and categorization of the intensity of exercise as moderate, heavy or severe $e^{8,10-13}$.

For the purposes of this study, the maximal lactate steady state (MLSS) was chosen as the gold standard method for estimating the aerobic/ anaerobic metabolic transition to identify ageand activity-related trends in aerobic capacity over time and the effects of physical training and/or physical detraining in long term associated to aging process. Despite these concerns, it is worth noting that a series of studies on aging and aerobic capacity have, indeed, been conducted using human subjects ${ }^{14-17}$. However, longitudinal studies with human subjects are associated with a significant loss to follow-up. So, animal models are used most often.

Addition, human diseases have long been simulated in laboratory animals ${ }^{18-21}$ for the purposes of studying the mechanisms of diseases on the molecular or systemic level. There is also great interest in understanding the response of several diseases and disease states to physical exercise and, specifically, in identifying the optimal intensity of physical exercise for disease prevention or treatment ${ }^{18,22-24}$.

Animal studies with training and subsequent detraining, evaluated the aerobic capacity between four ${ }^{25,26}$ and 10 weeks ${ }^{27,28}$ of physical training and between two $^{25,28}$ and four weeks ${ }^{26,27}$ of detraining physical, but few studies has evaluated the effects of long term of detraining physical ${ }^{29}$.

Thus, the aim of the present study was to analyze the aerobic capacity, through maximal lactate steady state (MLSS), in Wistar rats of different ages (at 2, 4, 6 and 12 months old) in response to physical conditioning and detraining at 12 months old at $80 \%$ of the maximal lactate steady state workload in rats.

\section{Method}

\section{Animals}

Albino Wistar rats aged 2-12 months were used. The animals were fed a balanced standard ration for rodents (Purina ${ }^{\circ}$ ), given water ad libitum, kept in collective cages ( 5 per cage) at room temperature $25{ }^{\circ} \mathrm{C}$ and exposed to a 12/12-hour light/dark photoperiod. All procedures involving the animals were subject to the approval by the Animal Use Ethics Committee of the Institute of Biosciences, UNESP - Rio Claro/Brazil in accordance with protocol number 2638 .

\section{Design and experimental groups}

The animals groups were divided for different ages and physical trained state:

- Group 2 Sedentary $(\mathrm{n}=8)$ - at 2 months old (youth);

- Group 4 Sedentary $(\mathrm{n}=8)$ - at 4 months old (young adult);

- Group 6 Sedentary $(\mathrm{n}=8)$ - at 6 months old (adult);

- Group 12 Sedentary $(\mathrm{n}=8)$ - at 12 months old (middle-aged); 
- Group 12 Trained $(\mathrm{n}=8)$ - physical training starting in young adulthood (at 4 months old) and lasting for the remainder of the study (until the animals were 12 months old). The animals were assessed at 12 months old.

- Group 12 Deconditioned ( $\mathrm{n}=8)$ - physical training starting in young adulthood (at 4 month old) and lasting for 4 months (until the animals were 8 months old). The animals were assessed at 12 months old.

\section{Body weight and adipose tissue}

Body weight was recorded once a week throughout the experiment. The adipose tissue from the posterior subcutaneous, mesenteric and retroperitoneal were analyzed. Mesenteric and retroperitonial are visceral regions of the adipose tissue, they usually are used as markers of visceral adiposity. We carried out the sum of the regions of subcutaneous fat, mesenteric and retroperitoneal.

\section{Maximal Lactate Steady State - MLSS}

For each animal, the identification of the metabolic transition zone, otherwise known as the aerobic capacity, was accomplished through protocol of maximal lactate steady state (MLSS). MLSS is the highest blood lactate concentration that can be kept stable during one exercise bout, and it represents the steady state at which the rate of lactate entry into the bloodstream equals the rate of lactate removal under a constant load of exercise $^{30}$. MLSS was used to evaluate and prescribe the training intensity ${ }^{31}$. Initially, the rats were adapted to the water to reduce the stress caused by the physical exercise in this environment. All evaluations were performed in individual water tanks that were kept at $30 \pm 1{ }^{\circ} \mathrm{C}$. Briefly, the animals were subjected to several increasingly intensity swimming tests every 48 hours, involving constant workloads in each test, as percentages of body weight, until MLSS concentrations were achieved. Each test lasted 25 minutes of continuous swimming and blood samples were taken from a small cut in the end of the tail every five minutes. Serum lactate concentrations were measured by means of a lactate analyzer (model YSI 1500 Sport, Yellow Springs, OH, USA). The MLSS was achieved once the difference in serum lactate concentrations between 25 and 10 minutes of exercise was equal to $1.0 \mathrm{mmol}^{\mathrm{L}} \mathrm{L}^{-1}$ or less ${ }^{31}$.

\section{Physical training}

The animals in the physical training groups (12 Trained and 12 Detraining) were subjected to swimming exercise for one hour per day, 5 days per week. Each animal supported a lead weight tied to its thorax that equaled $80 \%$ of the workload required to achieve that individual animal's baseline MLSS. The animals were reassessed every two months for their MLSS to ensure that they were training with a constant $80 \%$ of their MLSS workload.

\section{Statistical analysis}

The data are expressed as mean and standard deviations. The results were analyzed by means of variance analysis (two-way ANOVA) at a $5 \%$ significance level. Newman-Keuls post-hoc test was applied when needed. The correlations between workload and body weight in sedentary and trained animals were realized by Pearson's Correlation.

\section{Results}

TABLE 1 depicts the data on mean body weights (g) and adipose tissue. The mean body weight and adipose tissue, mainly the fat mesenteric, increased after two months of age, stabilized between 4 and 6 months and subsequently, increased once more by 12 months of age in sedentary and detrained rats. The mean body weight was maintained at the 4 and 6-month level in the group of exercising animals for the duration of the experiment. Animals trained 12 months have a lower fat these regions, mainly the fat mesenteric, of the groups 12 months sedentary or untrained, and similar at 4 and 6 months age. 
Different letters indicate statistically significant differences -

a\#b\#c - by Two-way ANOVA and NewmanKeuls post-hoc test, $p<0.05$.
TABLE 1 - Means and standard deviations of body weights (g) and the weights of adipose tissues (mg), including the mesenteric, retroperitoneal, subcutaneous tissues and total sum of fat adipose.

\begin{tabular}{cccccc}
\hline Groups & Body weight & Mesenteric & Retroperitoneal & Subcutaneous & Total sum \\
\hline 2 Sedentary & $260 \pm 28^{\mathrm{a}}$ & $1,105 \pm 250^{\mathrm{a}}$ & $987 \pm 419^{\mathrm{a}}$ & $692 \pm 177^{\mathrm{a}}$ & $18,486 \pm 291^{\mathrm{a}}$ \\
4 Sedentary & $454 \pm 47^{\mathrm{b}}$ & $2,123 \pm 651^{\mathrm{b}}$ & $2,665 \pm 724^{\mathrm{b}}$ & $1,743 \pm 510^{\mathrm{b}}$ & $43,789 \pm 550^{\mathrm{b}}$ \\
6 Sedentary & $507 \pm 18^{\mathrm{b}}$ & $2,475 \pm 537^{\mathrm{b}}$ & $2,383 \pm 365^{\mathrm{b}}$ & $1,499 \pm 381^{\mathrm{b}}$ & $44,151 \pm 638^{\mathrm{b}}$ \\
12 Sedentary & $588 \pm 71^{\mathrm{c}}$ & $4,399 \pm 643^{\mathrm{c}}$ & $3,191 \pm 703^{\mathrm{c}}$ & $1,896 \pm 758^{\mathrm{b}}$ & $51,314 \pm 994^{\mathrm{c}}$ \\
12 Trained & $515 \pm 72^{\mathrm{b}}$ & $3,007 \pm 811^{\mathrm{b}}$ & $2,604 \pm 1112^{\mathrm{b}}$ & $1,635 \pm 188^{\mathrm{b}}$ & $38,837 \pm 849^{\mathrm{ab}}$ \\
12 Detraining & $576 \pm 62^{\mathrm{c}}$ & $4,085 \pm 540^{\mathrm{c}}$ & $3,600 \pm 858^{\mathrm{c}}$ & $1,897 \pm 385^{\mathrm{b}}$ & $55,598 \pm$ \\
\hline
\end{tabular}

The blood lactate kinetics during the MLSS in FIGURE 1. In this example, the rat obtained determination test in one rat is exemplified

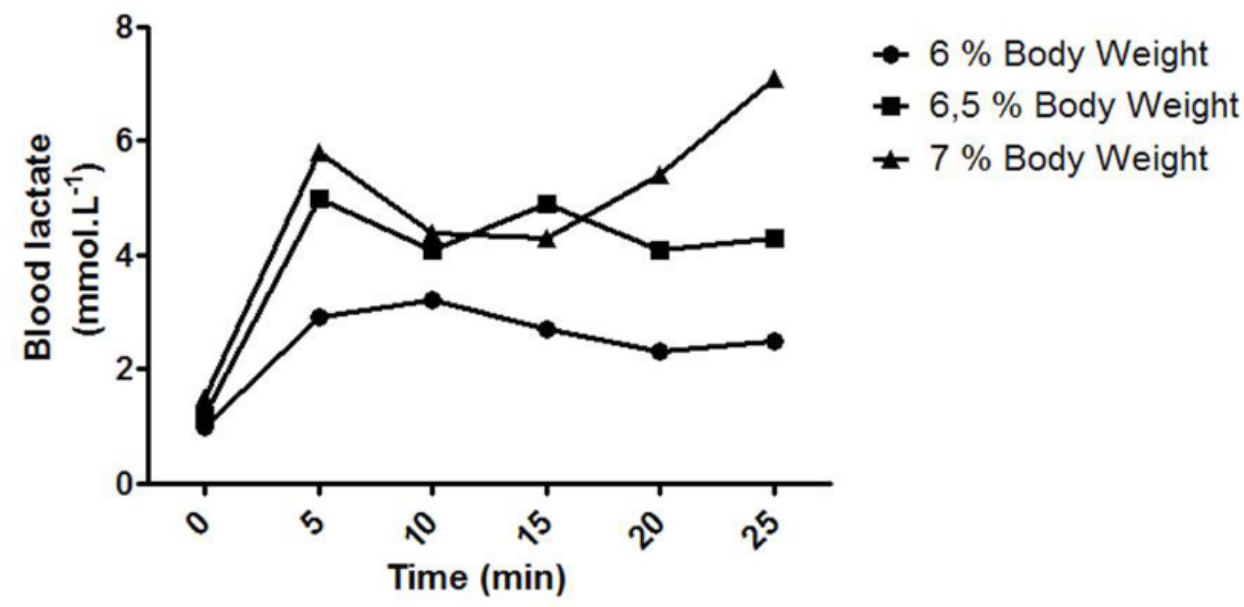

FIGURE 1 - Example the blood lactate kinetics during the MLSS determination test in one rat, the rat obtained MLSS at a 6,5\% load relative to body weight.

FIGURE 2 depicts serum lactate concentrations (mmol.L $\left.\mathrm{L}^{-1}\right)$ during exercise with a workload sufficient to achieve the MLSS. There were no statistically significant differences ( $\mathrm{p}>0.05$ ) among the groups. Additionally, the FIGURE 3 illustrates the various mean workloads at which the MLSS was reached, as aggregated by age and physical trained level. With increasing age, the mean workload to Group 12 Sedentary $(4.6 \pm 0.4 \% \mathrm{BW})$ required to reach the anaerobic threshold decreased $19.25 \%$ compared $(p<0.05)$ to Group 6 Sedentary $(5.8 \pm 1.0 \%$ body weight). In other hand, the physical exercise succeeded in reducing the loss of aerobic capacity that accompanied increasing age which is indicated by the greater in $25.19 \%(\mathrm{p}<0.05)$ and $8.60 \%$ ( $p>0.05)$ mean workload required to achieve the MLSS in the 12 Trained Group $(5.8 \pm 1.3 \%$ body weight), relative to the sedentary $(4.6 \pm 0.4 \%$ body weight) and detrained group $(5.3 \pm 0.4 \%$ body weight), respectively, of the same age. The workload in 12 Trained Group was $18.0 \%$ higher ( $p>0.05$ ) compared to Group 6 Sedentary.

Additionally, the load at MLSS shown significant correlation with body weight in sedentary animals $(\mathrm{r}=-0.71, \mathrm{p}<0.05)$, but only moderate correlation in trained animals $(\mathrm{r}=-0.40, \mathrm{p}<0.05)$, indicating that in detraining period, despite the increase in body weight, the aerobic capacity was maintained. 


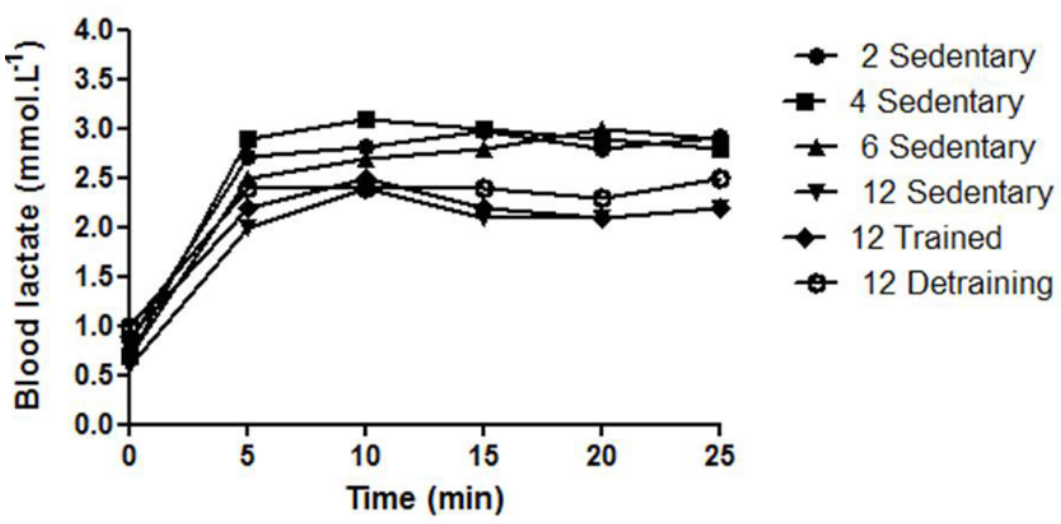

FIGURE 2 - Mean and standard deviation of serum lactate concentrations (mmol. $\left.\mathrm{L}^{-1}\right)$ at the MLSS in groups stratified by age and physical training level. 2 Sedentary - at 2 months old; 4 Sedentary - at 4 months old; 6 Sedentary at 6 months old; 12 Sedentary - at 12 months old; 12 Trained physical training at 4 months old until 12 months old; 12 Detraining - physical training at 4 months old until 8 months old and mantained sedentary until 12 months old.

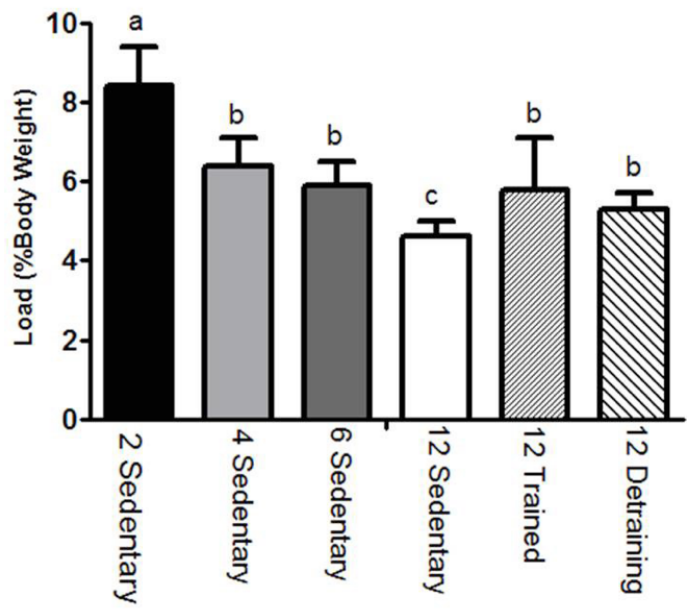

FIGURE 3 - Mean and standard deviation of workload associated with MLSS in groups stratified by age and physical training level. The different letters indicate statistically significant differences $-\mathrm{a} \# \mathrm{~b} \# \mathrm{c}-$ By two-way ANOVA and Newman-Keuls post-hoc test, $\mathrm{p}<0.05 .2$ Sedentary - at 2 months old; 4 Sedentary - at 4 months old; 6 Sedentary - at 6 months old; 12 Sedentary - at 12 months old; 12 Trained - physical training at 4 months old until 12 months old; 12 Detraining - physical training at 4 months old until 8 months old, and mantained sedentary until 12 months old.

\section{Discussion}

Physical exercise is more likely to produce the desired health benefits when it is prescribed on an individual basis and, tailored to the goals and physical capacity of each person. These benefits can be achieved regardless of any underlying metabolic or other healthrelated disorders an individual may possess ${ }^{32,33}$.

Our results show that the mean body weights of the study animals varied with age, increasing after the age of two months, which is a consequence of normal growth, and plateauing between 4 and 6 months when the animals were fully grown. Mean body weights increased again by age 12 months among the sedentary and detrained rats as consequence of increased body fat content in all regions analyzed (mesenteric, retroperitoneal and subcutaneous). According to the literature, 
physical training promotes weight maintenance and/or weight loss ${ }^{32,34,35}$ and indeed, the rats that engaged in 10 months of swimming exercise from the ages of 4-12 months remained at their 6-month weights for the study period, presumably through increased energy expenditure.

C57BL/6 mice trained for four weeks showed lower body weight than the sedentary group. However, after two weeks of physical detraining, no difference in body weight was observed between groups. The lipolytic activity stimulated by isoproterenol and citrate synthase activity increased in trained group, but was reversed by detraining. The activity of enzyme fatty acid synthase did not differ among groups ${ }^{25}$.

According to the results of the present study, the mean workload required to achieve the MLSS decreased with increasing age but less so with regular exercise, reflecting the dynamic nature of aerobic capacity, its responsiveness to physical conditioning and the importance of routinely reassessing the aerobic capacity of physically active animals.

In the present study, the mean workload that was required to achieve the MLSS varied between $5 \%$ and $8 \%$ of the animal's body weight, and aging process reduced the required workload. However, physical training was effective in preserving aerobic capacity, even in the animals that stopped training at 8 months. There were no significant differences between the mean workloads associated with the MLSS in the trained and detrained groups at 12 months old, and both were similar to the mean workloads for the 4- and 6-month groups. In contrast, the aerobic capacity (and the workload associated with the MLSS) decreased in the sedentary animals as they aged.

In current study, the mean workload associated with the MLSS among sedentary rats at 12 monthold was $5.1 \%$ of body weight, which is similar to $5.4 \%$ of body weight found in other study that also evaluated rats at 12 month-old ${ }^{36}$. Moreover, the serum lactate concentrations at steady state were similarly unaffected by age and physical training in both studies.

Ten weeks of exercise training increased in $23.5 \%$ the peak of maximum oxygen consumption $\left(\mathrm{VO}_{2 \text { peak }}\right)$ in young rats compared to sedentary rats. However, the $\mathrm{VO}_{\text {2peak }}$ declined after one and two weeks of detraining compared to trained group $^{28}$. In another study, after 10 weeks of training in adult Sprague Dawley rats, the $\mathrm{VO}_{2 \max }$ was higher that sedentary rats, and decreased
$50 \%$ within two weeks of detraining, and after 4 weeks, it was stabilized 5\% above sedentary rats. Additionally, the $\mathrm{VO}_{2 \max }$ was correlated with cardiomyocyte length, estimated cell volume, width, shortening ${ }^{27}$. In this way, Wistar rats 10 weeks old, $\mathrm{VO}_{2 \max }$ had increased significantly compared to control group following four weeks of exercise training. This improvement in aerobic capacity was accompanied by anatomical and physiological cardiac remodeling. However, these improvements were almost completely lost after detraining for the same period ${ }^{26}$.

The maximum oxygen consumption after 6 months of physical training and 10 weeks of interruption of this training in horses was maintained due to spontaneous activity during the day. And those changes in aerobic capacity were correlated with maximum speed changes and circulatory capacity during training and detraining ${ }^{29}$.

The endurance capacity during in an incremental running test to exhaustion and mitochondrial oxidative capacity muscles - citrate synthase and complex IV activity in plantaris and gastrocnemius muscles - were improved in 28-month-old Fischer $344 \times$ Brown Norway F1-hybrid (F344BN7) after 7 weeks of training ${ }^{37}$. In another study ${ }^{38}$, although, the exercise endurance time and peak velocity declined in the trained rats (at 36 months) at senescence compared with pre-training ( 29 month-old), it was always better than the control group. However, in these studies ${ }^{37,38}$ was using a rat strain more resistant to age-associated disease.

The differences among the mentioned studies may be due to methodological differences, such as ergometer (treadmill or swimming) and muscle mass involved, genre and species of animals, age of animals at the beginning of training, training and detraining time. However, no study has evaluated a physical training and detraining period so extensive in old animals, as the present research. Also, oftentimes the researches in animal models are criticized due to the lack of information about the intensity of effort performed during the physical exercise. So in present study we use the maximal lactate steady-state intensity to determine the exercise intensity, assessment procedure often use in our laboratory ${ }^{22-24,39}$. In human studies, the aerobic capacity and the workload required to reach the MLSS, of conditioned adolescents, of adults under 50 years old and of men more than 50 years old decrease with age without affecting the serum lactate concentrations at steady state ${ }^{15}$. 
TAKeshima et al..$^{40}$, also conducting a study with human subjects, found that $\mathrm{VO}_{2 \max }$, is higher in exercise-trained elderly individuals compared with sedentary or detrained individuals of the same age. This study shows that physical activity mitigates the loss of aerobic capacity that is associated with advancing age.

The age-associated reduction in the workload that is required to achieve the MLSS is probably a truly age-related phenomenon, one that may be mediated through the glycogenic pathway and/or the lactate transport process ${ }^{41}$. Regardless of the specific biochemical pathways are most directly responsible for the reduction in aerobic capacity, physical exercise and training may exert a mitigating effect at this level. It is becoming increasingly wellestablished that aging is associated with a reduction in the aerobic capacity of sedentary animals but that physical exercise can effectively attenuate the deleterious effects of age and prevent obesity.

In summary, the physical training in long term protected against the increased of the body weight and fat depots in many body regions, caused by aging. However, this effect was abolished by deconditioning physical. Additionally, the physical training prevented the decrease the aerobic capacity due the aging process and this effect was maintained after detraining physical.

\section{Resumo}

Capacidade aeróbia de ratos da linhagem wistar: efeito do treinamento físico e do destreinamento físico na meia idade

Tem sido demonstrado que o engajamento em exercícios físicos regulares gera benefícios para a saúde a curto e a longo prazo, principalmente a redução do risco de doença cardiovascular, mas pouco se sabe sobre o destreinamento físico no processo de envelhecimento. 0 objetivo do presente estudo foi analisar a capacidade aeróbia, através da máxima fase estável de lactato (MFEL), em ratos Wistar de diferentes idades e em resposta ao treinamento e ao destreinamento físico em ratos de meia-idade. Os resultados foram significativos para o ganho de peso corporal no grupo sedentário (588 $\pm 71 \mathrm{~g}$ ) e animais destreinados com 12 meses ( $576 \pm 62 \mathrm{~g}$ ), enquanto o grupo treinado manteve o peso corpo semelhante aos animais - PC $(515 \pm 72 \mathrm{~g})$, do grupo de quatro meses $(455 \pm 17 \mathrm{~g})$ e seis meses de idade $(471 \pm 37 \mathrm{~g})$. Como medida da capacidade aeróbia, a MFEL diminuiu com a idade ( 2 meses sedentários $(8,4 \pm 1 \% \mathrm{PC}$ ), 4 meses sedentários $(6,4 \pm 0,6 \% \mathrm{PC}), 6$ meses sedentários $(5,8 \pm 1 \% \mathrm{PC}), 12$ meses sedentários $(5.1 \pm 0,7 \% \mathrm{PC})$, mas o exercício físico foi eficaz em atenuar a perda da capacidade aeróbia relacionada com a idade, o grupo 12 meses treinados $(5,8 \pm 1,3 \%$ PC) e o grupo destreinado $(5,3 \pm 0,4 \%$ PC) tiveram resultados semelhante na capacidade aeróbia. 0 treinamento físico de longo prazo protege contra o aumento do peso corporal e o aumento de depósitos de gordura causada pelo envelhecimento. Porém, este efeito foi abolido pelo destreinametno físico. Além disso, o treinamento físico preveniu a diminuição da capacidade aeróbia, devido ao processo de envelhecimento e este efeito foi mantido após destreinamento físico.

PalaVRAS-Chave: Envelhecimento; Doenças Metabólicas; Máxima Fase Estável de Lactato; Exercícios; Destreinamento; Ratos de Meia-Idade.

\section{References}

1. Alcock L, O'Brien TD, Vanicek N. Age-related changes in physical functioning: correlates between objective and self-reported outcomes. Physiotherapy. 2015;101(2):204-13.

2. Cadore EL, Izquierdo M. Exercise interventions in polypathological aging patients that coexist with diabetes mellitus: improving functional status and quality of life. Age (Dordr). 2015;37(3):64.

3. Wareham NJ, Wong MY, Hennings S, et al. Quantifying the association between habitual energy expenditure and blood pressure. Int J Epidemiol. 2000;29(4):655-60. 
4. Haveman-Nies A, de Groot LC, van Staveren WA. Dietary quality, lifestyle factors and healthy ageing in Europe: the SENECA study. Age Ageing. 2003;32(4):427-34.

5. Twisk JW, Kemper HC, van Mechelen W. The relationship between physical fitness and physical activity during adolescence and cardiovascular disease risk factors at adult age. The Amsterdam Growth and Health Longitudinal Study. Int J Sports Med. 2002;23(Suppl 1):S8-14.

6. Blair SN, Brodney S. Effects of physical inactivity and obesity on morbidity and mortality: current evidence and research issues. Med Sci Sports Exerc. 1999;31(Suppl 11):S646-62.

7. Varady KA, Ebine N, Vanstone CA, Parsons WE, Jones PJ. Plant sterols and endurance training combine to favorably alter plasma lipid profiles in previously sedentary hypercholesterolemic adults after 8 wk. Am J Clin Nutr. 2004;80(5):1159-66.

8. Billat VL, Sirvent P, Py G, Koralsztein JP, Mercier J. The concept of maximal lactate steady state: a bridge between biochemistry, physiology and sport science. Sports Med. 2003;33(6):407-26.

9. Beneke R. Methodological aspects of maximal lactate steady state-implications for performance testing. Eur J Appl Physiol. 2003;89(1):95-9.

10. Londeree BR. Effect of training on lactate/ventilatory thresholds: a meta-analysis. Med Sci Sports Exerc. 1997;29(6):837-43.

11. Gaesser GA, Poole DC. The slow component of oxygen uptake kinetics in humans. Exerc Sport Sci Rev. 1996;24:35-71.

12. Denadai BS, Figueira TR, Figuera TR, Favaro OR, Gonçalves M. Effect of the aerobic capacity on the validity of the anaerobic threshold for determination of the maximal lactate steady state in cycling. Braz J Med Biol Res. 2004;37(10):1551-6.

13. Madrid B, Oliveira Pires F, Prestes J, et al. Estimation of the maximal lactate steady state intensity by the rating of perceived exertion. Percept Mot Skills. 2016;122(1):136-49.

14. Trappe SW, Costill DL, Vukovich MD, Jones J, Melham T. Aging among elite distance runners: a 22-yr longitudinal study. J Appl Physiol (1985). 1996;80(1):285-90.

15. Mattern CO, Gutilla MJ, Bright DL, Kirby TE, Hinchcliff KW, Devor ST. Maximal lactate steady state declines during the aging process. J Appl Physiol (1985). 2003;95(6):2576-82.

16. Gram M, Vigelsø A, Yokota T, Helge JW, Dela F, Hey-Mogensen M. Skeletal muscle mitochondrial H2 O2 emission increases with immobilization and decreases after aerobic training in young and older men. J Physiol. 2015;593(17):4011-27.

17. Chmelo EA, Crotts CI, Newman JC, Brinkley TE, Lyles MF, Leng X, et al. Heterogeneity of physical function responses to exercise training in older adults. J Am Geriatr Soc. 2015;63(3):462-9.

18. Botezelli JD, Mora RF, Dalia RA, et al. Exercise counteracts fatty liver disease in rats fed on fructose-rich diet. Lipids Health Dis. 2010;9:116.

19. Cambri LT, Ghezzi AC, Ribeiro C, Dalia RA, de Mello MA. Recovery of rat growth and lipid profiles in adult rats subjected to fetal protein malnutrition with a fructose-rich diet. Nutr Res. 2010;30(2):156-62.

20. Ghezzi AC, Cambri LT, Botezelli JD, Ribeiro C, Dalia RA, de Mello MA. Metabolic syndrome markers in wistar rats of different ages. Diabetol Metab Syndr. 2012;4(1):16.

21. Cambri LT, Ghezzi AC, Arsa G, Botezelli JD, de Mello MA. Standard short-term diet ameliorates the lipid profile altered by a fructose-rich diet in rats. J Dev Orig Health Dis. 2015;6(4):335-41.

22. Cambri LT, Dalia RA, Ribeiro C, Rostom de Mello MA. Aerobic capacity of rats recovered from fetal malnutrition with a fructose-rich diet. Appl Physiol Nutr Metab. 2010;35(4):490-7.

23. Ghezzi AC, Cambri LT, Ribeiro C, Botezelli JD, Mello MA. Impact of early fructose intake on metabolic profile and aerobic capacity of rats. Lipids Health Dis. 2011;10:3.

24. Ribeiro C, Cambri LT, Dalia RA, et al. Muscle protein metabolism in neonatal alloxan-administered rats: effects of continuous and intermittent swimming training. Diabetol Metab Syndr. 2012;4(1):5.

25. Mazzucatto F, Higa TS, Fonseca-Alaniz MH, Evangelista FS. Reversal of metabolic adaptations induced by physical training after two weeks of physical detraining. Int J Clin Exp Med. 2014;7(8):2000-8.

26. Waring CD, Henning BJ, Smith AJ, Nadal-Ginard B, Torella D, Ellison GM. Cardiac adaptations from 4 weeks of intensitycontrolled vigorous exercise are lost after a similar period of detraining. Physiol Rep. 2015;3(2).

27. Kemi OJ, Haram PM, Wisløff U, Ellingsen $\varnothing$. Aerobic fitness is associated with cardiomyocyte contractile capacity and endothelial function in exercise training and detraining. Circulation. 2004;109(23):2897-904.

28. Evangelista FS, Martuchi SE, Negrão CE, Brum PC. Loss of resting bradycardia with detraining is associated with intrinsic heart rate changes. Braz J Med Biol Res. 2005;38(7):1141-6.

29. Mukai K, Ohmura H, Hiraga A, et al. Effect of detraining on cardiorespiratory variables in young thoroughbred horses. Equine Vet J Suppl. 2006(36):210-3.

30. Heck H, Mader A, Hess G, Mücke S, Müller R, Hollmann W. Justification of the 4-mmol/l lactate threshold. Int J Sports Med. 1985;6(3):117-30. 
31. Gobatto CA, de Mello MA, Sibuya CY, de Azevedo JR, dos Santos LA, Kokubun E. Maximal lactate steady state in rats submitted to swimming exercise. Comp Biochem Physiol A Mol Integr Physiol. 2001;130(1):21-7.

32. Powell KE, Paluch AE, Blair SN. Physical activity for health: What kind? How much? How intense? On top of what? Annu Rev Public Health. 2011;32:349-65.

33. Miller FL, O'Connor DP, Herring MP, et al. Exercise dose, exercise adherence, and associated health outcomes in the TIGER study. Med Sci Sports Exerc. 2014;46(1):69-75.

34. Carpenter KC, Strohacker K, Breslin WL, Lowder TW, Agha NH, McFarlin BK. Effects of exercise on weight loss and monocytes in obese mice. Comp Med. 2012;62(1):21-6.

35. Miller GD, Nicklas BJ, Davis CC, Legault C, Messier SP. Basal growth hormone concentration increased following a weight loss focused dietary intervention in older overweight and obese women. J Nutr Health Aging. 2012;16(2):169-74.

36. Cunha RR, Cunha VN, Segundo PR, et al. Determination of the lactate threshold and maximal blood lactate steady state intensity in aged rats. Cell Biochem Funct. 2009;27(6):351-7.

37. Betik AC, Baker DJ, Krause DJ, McConkey MJ, Hepple RT. Exercise training in late middle-aged male Fischer $344 \times$ Brown Norway F1-hybrid rats improves skeletal muscle aerobic function. Exp Physiol. 2008;93(7):863-71.

38. Betik AC, Thomas MM, Wright KJ, Riel CD, Hepple RT. Exercise training from late middle age until senescence does not attenuate the declines in skeletal muscle aerobic function. Am J Physiol Regul Integr Comp Physiol. 2009;297(3):R744-55.

39. Cambri LT, Ribeiro C, Botezelli JD, Ghezzi AC, Mello MA. Muscle glycogen metabolism changes in rats fed early postnatal a fructose-rich diet after maternal protein malnutrition: effects of acute physical exercise at the maximal lactate steady-state intensity. Diabetol Metab Syndr. 2014;6(1):118.

40. Takeshima N, Kobayashi F, Watanabe T, Tanaka K, Tomita M, Pollock ML. Cardiorespiratory responses to cycling exercise in trained and untrained healthy elderly: with special reference to the lactate threshold. Appl Human Sci. 1996;15(6):267-73.

41. Bois-Joyeux B, Chanez M, Peret J. Age-dependent glycolysis and gluconeogenesis enzyme activities in starved-refed rats. Diabete Metab. 1990;16(6):504-12.

\section{Acknowledgments}

We are grateful to the São Paulo Research Foundation (FAPESP/Process10/12896-0). We thank José Roberto R. Silva for technical assistance. This manuscript was translated for proper English Language by native speaking editors at American Journal Experts.

\section{Conflict of interest}

The authors have no conflicts of interest, and no section of the article has been or will be published in another journal.

ADDRESS

Ana Carolina Ghezzi

Av. 24-A, 1515 - Bela Vista 13506.90o - Rio Claro - SP - BRAZIL e-mail: carolghezzi@gmail.com
Submitted: 10/o8/2016

Revised: 25/11/2016

Accepted: 25/o1/2017 
